\title{
Discussion on the Human Resources Development of Top Female Executives in Enterprises
}

\author{
Zhang Binqi \\ School of Economics and Managemenl, Hainan University, Hainan Haikou 570100
}

Keywords: top female executives; administrative staff; human resources

\begin{abstract}
Scientific and effective human resources development of top female executives can enable enterprises to maintain long-term competitiveness. Therefore, it is necessary to enhance the company's competence and promote the full development of the enterprise. This paper analyzes the human resources development of top female executives, discusses the problems existed, and proposes their own opinions, so as to provide a reasonable basis for it

When women become executives, they should make good use of women's unique personality as a shortcut to enhance the leadership. The proper management of women's unique personality makes them more attractive and successful. When competing with male executives, women executives should not lose their femininity.
\end{abstract}

\section{The significance of cultivating senior women for enterprise development}

Women in the new era are wise, tough, tolerant and considerate. As a successful woman, there should not only be a successful career, but also a wonderful personal life.

In the workplace, they manage rationally and make decisive decisions immediately; In the social situations, they are graceful and elegant; On the platform, they are calm and distinguished. No matter under what situations, they are confident, optimistic, calm, strong, with a stable mood, independent positive, determined, calm, to face the reality of the defects and setbacks, to overcome the traditional conservative of women, fear of inferiority, and also the attachment. Positive and optimistic, aggressive, dare to competition, unyielding and forge ahead, is the one who has a strong sense of modern intellectual women, to face all challenges, to win the respect and recognition, social family's trust and support, realize their own value, breakthrough development bottleneck, run towards to the peak period of the development of themselves.

Women focus on methods, they prefer to take the cooperative, participative leadership. Women do better at change, and also they work harder to gain the trust and respect of their followers. They are more willing to delegate, to help underlings reach their potential and to benefit more people from the organization. The changes of the times are consistent with the temperament of women. Managing director Mintzberg also pointed out that companies need to cultivate and care for staff, and caring is a more feminine management style. Attractive female executives always stand out from the crowd. They have clear thinking and leisurely pace. There is charming and fascinating aura in fresh air, which shows a kind of extraordinary tranquility. In front of them, the most secular people will be mild and gentle.

\section{The main problems existing in the human resources management of female executives in} Chinese enterprises

\subsection{Imperfect human resource management system}

Most companies in our country do not implement specific human resources management for female employees, nor do they analyze the human resources management model of female executives. In accordance with the needs of corporate development strategies, they should work out a unified plan for women employees including management and develop effective assessment 
criteria. Companies have great problems in the incentive system and performance appraisal of women. The specific manifestation is single and unilateral human resource management and backward management tools and management models. There is no adequate and comprehensive preparation before the work, which leads to difficulty in handling unexpected situations. It is hard for an enterprise to manage and track female employees' whole-day work processes.

\subsection{The salary of female senior managers is not reasonable}

\subsubsection{The incomplete salary structure}

Salary is the reward that employees receive through labor, so salary must be closely linked to the value that brought by the female senior managers. The design ideas of the enterprise's salary system generally take the position, academic record, title and so on for reference. If the positions are the same, then no matter what position the employee is in, how about the performance, the salary will be the same. The salary usually only has a fixed part, if there is no flexibility, there is no effect of motivation; furthermore, long hours, low wages, no guarantees, and no good welfare system, no overall career planning, also make female senior managers feel insecure because their long-term interests cannot be guaranteed.

\subsubsection{The unreasonable salary structure of enterprise}

There is little connection between salary structure of enterprise and the performance. In particular, there is little effect of motivation for project managers, high-level technical personnel and project contractors as well as improving the training acceptance of employees and their performance. Many female senior managers in enterprises are generally dissatisfied with the current situation of compensation and welfare, and it is difficult to effectively motivate employees to work hard and actively. Failing to deal with the relationship between qualifications, position, ability, wisdom and contribution in the compensation distribution system, the concept of "work according to your ability, get your pay by contribution” has not been well reflected.

\subsection{The imperfect human resources management regulations of female management personnel}

It is relatively late for enterprises to introduce the human resources management model. This directly leads to the backwardness and lag of the enterprise human resources management model. The research on the value of human resources is also relatively slow. During the process of human resources development for employees, due to the lacking of relevant laws and regulations, the unfair phenomenon of employees occurs. Enterprises should further strengthen the human resources management model and human resource management concepts, and further improve the company's human resources management theory. The employees of the company do not fully play their role in the work process. Some people's self-protection awareness is still rather poor. The company still lacks a lot of self-confidence for the employees. It is not very perfect of self-management and selfeducation.

\section{Countermeasures to improve the human resources management level of female top management in China}

\subsection{Improve the human resources management system for female top management personnel}

In the process of corporate ethics construction management, human resources management is mainly embodied in perfect management systems and management tools, which can effectively avoid the loss of employees' efficiency and morality in their work. Human resources management should choose a management model with a relatively high degree of credibility and strengthen the company's own culture. In the process of human resources management, construction companies should adhere to the people-oriented management system and implement the enterprise's human resources moral construction. This is of great significance to the development of construction companies. 


\subsection{Build a dynamic salary system and incentive mechanism}

Establish a long-term effective salary model based on the local economic level and price level, make appropriate adjustments to wages to increase employee income. Enterprises should also establish a minimum wage protection model for their employees so that employees can work with no worries. Only change is the only constant phenomenon that characterizes the information age. In the 1990s, advances in computer and data processing technologies have expanded the role of human resources information systems. These advances have made various scales and the Internet have become one of the main channels for enterprises to release and obtain information on human resources activities. The desire to keep track of and monitor the contribution of human resources activities to enterprises has gradually become a reality.

\subsection{The Improvement of the Human Resources Management Regulations for Senior Female Managers}

The Enterprise should establish the sound human resources protection system, implement the human resource management system suitable for the development of female talents, accelerate corporate culture construction, increase the enthusiasm of female senior management personnel in the work process and establish the management system suitable for talents, constantly improve the work and cultural environment and highlight the development of female senior management personnel toward personalization. Construction enterprise should establish sound corporate rules and regulations to ensure the healthy and stable development of developing enterprises.

\section{Case analysis}

\subsection{Character profile}

Dong Mingzhu was born from Nanjing in Jiangsu Province. She is an entrepreneur. She graduated successively from Anhui Wuhu Vocational and Technical College, EMBA2008 of Zhongnan University of Economics and Law, a postgraduate from the School of Economics under the Chinese Academy of Social Sciences and EMBA of China Europe International Business School. In 1990, she entered Gree as a business manager. In 1994, she successively took the posts of Director of Operations, Deputy General Manager and Vice Chairman of Zhuhai Gree Electric Appliance Co., Ltd. And in May 2012, she was appointed as the chairman of Gree Group. Re-elect the tenth, eleventh, twelfth and thirteenth National People's Congresses, served as a member of the Democratic National Construction Central Committee, vice chairman of the Guangdong Provincial Women Entrepreneurs Association, honorary president of the Zhuhai Red Cross Society and other positions. Dong Mingzhu can endure hardship, independence and disobedience.

\subsection{Case analysis}

In 1994, Gree announced a major crisis, the salesman of the main business department had a "resignation" crisis, and Dong Mingzhu resisted the temptation to stay in Gree and was unanimously recommended as director of Operations. In 1996, air conditioning industry Cold and Summer showdown hardship. However, Dong mingzhu prefers to abandon the market is not devaluation. She led the 23 sales clerk, with thousands of other manufacturers gathered 100 step marketing team. In Aug. 31, she divided the profit of 100 million yuan into 2 percentage points based on the sales ratio, prompting its annual sales of Gree by $17 \%$. This is the first time that Chunlan has been cross-owned.

Since then, Gree has been China's number one in sales, expenses, and market share for 10 years.

In 2001, Dong Mingzhu became the general manager of Gree Electric. At that moment, Dong Mingzhu should have a committee.

By 2012, Gree had completed sales of US $\$ 100$ billion. In the past eight years, its sales of air conditioners have ranked first in the world. Gree officially opened the "Dong Mingzhu era" with highly concentrated power. In 2007, Dong Mingzhu's annual salary exceeded 1 million to 1.33 million yuan. In 2009, this figure increased to 2.1 million yuan, and doubled in two years to 4.75 
million yuan.

\section{Conclusion}

Enterprises should attach importance to team building, attach importance to collaboration and communication, and make female senior management personnel participate in management as the pursuit goal. Only in this way will the enterprise be full of development dynamism, and the senior female managers of enterprises will become the company's resources for development of nuclear bombs.

\section{References}

[1] Guan Peilan, Guo Yunfei. An Analysis of the Obstacles of Women's Human Resources Development[J]. China's Human Resources Development. 2016(06)

[2] Zhang Jingyuan. Analysis of the advantages of female managers in the development of enterprises[J]. Business Manager. 2016(18)

[3] Xu Wen. The contradiction between female managers' gender and management[J]. Xiang Chao (the second half) (theory). 2017(12) 